\title{
SENSORY IDENTIFICATION OF COLA-TYPE SOFT DRINKS AMONG STUDENTS
}

\author{
Leszek RYDZAK ${ }^{1 *}$, Katarzyna KOZŁOWICZ², Monika STOMA³ ${ }^{3}$, Agnieszka DUDZIAK ${ }^{4}$, \\ Marcin NATONIEWSKI ${ }^{5}$ \\ ${ }^{1}$ University of Life Sciences in Lublin; leszek.rydzak@up.lublin.pl, ORCID: 0000-0002-9359-4412 \\ ${ }^{2}$ University of Life Sciences in Lublin; katarzyna.kozlowicz@up.lublin.pl, ORCID: 0000-0002-1922-7577 \\ ${ }^{3}$ University of Life Sciences in Lublin; monika.stoma@up.lublin.pl, ORCID: 0000-0003-0404-699X \\ ${ }^{4}$ University of Life Sciences in Lublin; agnieszka.dudziak@up.lublin.pl, ORCID: 0000-0002-4884-5403 \\ ${ }^{5}$ University of Life Sciences in Lublin; marcin.natoniewski@gmail.com, ORCID: 0000-0002-9832-3515 \\ * Correspondence author
}

Purpose: The aim of the study was to make an attempt at evaluating factors that affect the choice and, consequently, purchase and consumption of selected brands of cola-type beverages by students of Lublin universities.

Design/methodology/approach: The study was followed by testing sensory recognition of a selected brand of a cola-type beverage. The applied research tool was a survey containing closed-ended and open-ended questions regarding the subject related to the beverage market in Poland. The study was conducted among 100 students of Lublin universities, both male and female, at various age.

Findings: The collected results were processed using statistical analysis tools. The drink that was most often selected among the students proved to be Coca-Cola. In the chosen market segment, consumers also show a strong attachment to the brand. At the end of the study, selected cross analyses were performed, which provided an answer to how smoking cigarettes and alcohol consumption affect sensory sensitivity in the study group of students.

Originality/value: A novelty in the work is the use of a question in the survey regarding sensory recognition that eliminates the subjectivity of surveys. The respondent may recognize the brand or not.

Keywords: brand, sensory recognition, cola-type beverage market in Poland.

\section{Introduction}

At present, in the globalised culture and economy it is difficult to meet a person who has never had any physical contact with a cola-type beverage or who has never heard of it. It can be claimed that it is the world's most recognizable soda drink type. Beverages of this type are produced by many companies with the Coca-Cola company being the unquestionable 
leader in this market segment. The company itself does not produce the drink but its twoingredient concentrate, which is then transported to a number of bottling facilities around the world, most often by air. Soda drink consumption in Europe amounts to over 20 million litres. Over half of this market is dominated by Coca-Cola (Szymańska, 2005).

The term "brand" is not present in the legal system. However, what is referred to in marketing as a 'brand' is terminologically reflected in law.

Protection of a brand can be coded in the following words: a company, a mark of an entrepreneur or their products, a trademark, personal rights of both natural and legal persons, and organisations (Popiel, 2005).

There are many definitions of this concept, yet they all stress that it pertains to the product, the brand name, the packaging, the advertisement and related activities concerned with distribution and the price. It is a combination of the concepts that differentiates the offer of a given producer from competitive offers and provides the consumer with functional and/or symbolic advantages. A brand is a value that creates the local group of buyers and thus allows the producer to achieve the leading position on the market (Dębski, 2009).

Owing to a brand and its development, a product can be distinguished from other similar products on the market. As a result, clients can be sure of a specific level of quality of the offered goods and the standards a given products represents, which in turn makes a purchase an informed choice (Chrąchol, 2009).

An important matter when creating and building a brand is obtaining knowledge about the client. Another very important element is to keep previous clients and to adapt one's products to their needs by ongoing monitoring of their purchase habits (Altkorn, 1999).

The name of a brand is one of the most obvious elements that relates the product to the brand it represents. It is a constituent that facilitates differentiation of a given product or a company on the market (Urban, 1998). It is to products what first and last names are to people (Altkorn, 1999; Chrąchol, 2009).

The basic functions of a brand are: evoking specific association in the customer, differentiating the product from others that fulfil similar needs, increasing the product's recognition or facilitating communication between market participants (Chrąchol, 2009).

Over the years, consumers' requirements regarding food products they purchase have been growing. First of all, buyers pay much attention to sensory properties that have a considerable influence on how a product is perceived by the buyer and, hence, more complex sensory analysis tools, owing to which they become increasingly more effective. Although the very same products evoke different sensory experiences in each person, sensory analysis tools are objective (Marzec and Gondek 2007).

In the economy there is a number of companies manufacturing food products that fulfil the same needs and have similar organoleptic properties, yet differ in terms of quality, marking, appearance and packaging volume, as well as their names. QA sensory analysis allows one to identify differences among them. It is also conducted when a new product is introduced on the 
market. A sensory analysis is an organoleptic evaluation aimed at determining properties of a given product using human senses (sight, taste, smell, touch, hearing) since they are a particular measurement tool. During the analysis it is highly important that proper evaluation conditions are ensured (Babicz-Zielińska et al. 2009).

A sensory analysis is a test necessary for determining a product quality. Owing to such tests being conducted, producers can specify marketing targets, develop a better product recipe or increase the attractiveness of their product. These tests require neither laborious effort nor high financial contribution. This measurement aims at determining how a person subject to this study reacts to the tested product, what are his or her preferences regarding a given product and to what extent is he or she satisfied with the quality of the tested product. Owing to the use of the senses test results are obtained in a short time. A sensory analysis is also carried out by producers on an ongoing basis during production processes mainly to keep the standard of the product on a constant level (Baryłko-Pikielna and Matuszewska 2009).

A sensory analysis can be divided into two groups. The first is consumer studies and the second is sensory analytical tests. Differences among the two are presented in Table 1.

\section{Table 1.}

Differences between a consumer study and a sensory analytical test

\begin{tabular}{|c|l|}
\hline \multicolumn{1}{|c|}{ Consumer studies } & \multicolumn{1}{c|}{ Sensory analytical tests } \\
\hline - testing of recipients' reaction to products, & - ensured sensory quality of products, \\
- investigation of the consumer's preferences & - comparison of quality of competing products, \\
regarding a product ('I like it" or "I don't like it"), & - developing new products, \\
- control of the efficiency of marketing campaigns, & - the test is conducted on a trained team (from 6 to 15 \\
- the study is conducted on a non-trained group of & evaluators) in a laboratory of sensory analyses, \\
tasters (100 or more people) in public places & - identification of differences, \\
(universities, shopping malls, etc.) & - comparison with the standard, \\
& - a descriptive analysis, \\
\hline
\end{tabular}

Adapted from: Baryłko-Pikielna and Matuszewska, 2009.

Among laboratory methods for performing a sensory analysis, we can distinguish the following:

- the QDA - a quantitative descriptive analysis,

- the sequence (order) method,

- the method of altered intensity of sensory experiences in time (time - intensity),

- the scaling method,

- the difference identification method (differential).

The quantitative descriptive analysis (QDA) - one of the most multi-level and at the same time one of the fastest developing methods of sensory analysis - is also referred to as the conventional profiling method. This method is most often used for making new food products. The main assumption of this method is that specific traits of a product, i.e. taste, smell or structure, do not make up separate qualitative characteristics of the product but constitute an aggregated experience (Baryłko-Pikielna and Matuszewska, 2009). The quantitative method is also used in studies that involve observation of changes in sensory quality levels. 
This method entails describing each trait by introducing it onto a numeric or linear scale with proper border specifications maintained. Next, results are translated into a corresponding numeric value, which is then followed by statistical processing and presenting the final results in the form of diagrams. Most often, these are bar charts or polar diagrams (Baryłko-Pikielna and Matuszewska, 2009).

The sequence (order) method - consists in classifying samples subject to evaluation regarding a specific qualitative trait. This can be exemplified by putting orange juice samples in order from the least sour to the sourest - at first, the sequence of the samples is random. The difficulty level of the test is determined by the size of differences between samples (the lesser the difference of taste of the tested product, the higher the level of difficulty of the conducted test), whereas advantages of this method involve practicality, low costs and short time necessary for carrying out the test. In the sequence method, during the evaluation of the results Kramer's table is used.

The method of altered intensity of sensory experiences in time (time - intensity) - consists in ongoing observation and tracking of changes in sensory intensity, observing changes in time and also making a detailed record of the changes and their occurrence over time. This test can provide necessary information about the product that cannot be obtained when using other methods of sensory analysis. In this method, the representative group that takes part in the study should be properly prepared and subject to a specialist preparatory training, as well as have a system for ongoing record of changes in the sensory evaluation (Małecka, 2003; Budsławski and Drabant, 1972).

The scaling method - its task is to present the quality and intensity of sensory traits of the reviewed product based on selected characteristics in a quantitative manner. The main assumption in this method is that each number or a score on the scale is directly proportional to the intensity of qualitative traits of the evaluated product. This method employs various types of scales (PN-ISO 4121:1998). A scale is tasked with attributing verbal terms to the corresponding quality level. These terms are either specifically selected for a given product or general. These scales are more or less complex depending on the needs. These are most often 5,7 or 9 -point scales. The evaluator is tasked with marking numbers on the scale that correspond to his or her experiences during the test.

The aim of the difference identification method is to identify differences in sensory quality. It is one of the oldest methods applied in a laboratory sensory analysis and determines changes of a selected qualitative trait. Among difference identification methods we distinguish the even method in which samples are compared in pairs. The aim of this method is to determine differences in the sensory quality of products regarding the investigated trait, e.g. crunchiness, sweetness. The evaluator is tasked with identifying the sample that according to him or her is, e.g. crunchier than other samples. Results of statistical significance of differences are determined suing special statistical tables (Gawęcki and Jędryka, 2001). 
Another method classified as a difference identification method is the duo-trio method that consists in comparing two samples, one of which is a standard sample and the other is characterised by other organoleptic properties. The evaluator is tasked with identifying the reference sample and one that does not fit the reference. Results are evaluated using the very same tables as in the case of the even method (Baryłko-Pikielna and Matuszewska, 2009).

The last method classified as a difference identification method is the triangle method that consists in comparing three samples, two of which are identical and the third one is different regarding the investigated trait. The study participant is tasked with identifying two identical samples and one that is different. During the evaluation of results in this method the very same tables as in the even method are applied (Gawęcki, 2015; Baryłko-Piekielna and Matuszewska, 2009).

Methods of consumer sensory analysis can be divided into two groups.

The first one is the preference group where evaluators choose samples which they find most interesting, most desired by consumers compared to other samples. Usually, samples are evaluated from the best to the worst. In this research method at least two samples are required (Baryłko-Pikielna and Matuszewska, 2009).

The other is the acceptance group. In this method a considerable role is played by a subjective reference to the tested sample which determines that it is selected. In the acceptance group, during testing hedonic scales and their varieties are employed. The most often applied are 10-point hedonic scales. The evaluation may consist in a general acceptance of a given product and its individual traits (colour, taste, crunchiness) (Baryłko-Piekielna and Matuszewska, 2009).

A consumer sensory analysis takes place in several steps. The first one is sample preparation, which is determined by the product to be tested and then on this basis a sensory analysis evaluation is conducted. The method applied to perform the analysis is also significant. Food products such as fish, potatoes, meat or poultry must be subject to strictly monitored thermal treatment. Food products such as flavourings or spices are diluted before testing to the degree they are usually consumed. This treatment does not affect their qualitative characteristics. Food products such as crisps, sweets, crisp bread or margarine are evaluated in an unaltered state (Baryłko-Piekielna and Matuszewska 2009). Prior to the sensory analysis, it is necessary that a number of conditions related to the study are met. These are: anonymity (each sample should be described by a code only), type of vessels (they must not alter the organoleptic properties of the product), constant temperature characteristic for a given product, the same size of samples, various order of presenting the samples (Gawęcki, 2015). 


\section{Methods}

The aim of the research was to make an attempt at evaluating factors that affect cola-type soft drinks consumption among students of Lublin universities and assessing the sensory recognition of a selected cola beverages brand. The study material was collected by means of a survey. In the study, an anonymous questionnaire was used comprising close-ended and openended questions on the subject related to cola type beverages. In the conducted questionnaire survey nonprobability sampling was applied. The study was conducted among 100 students of Lublin universities, both male and female, of different age. The students studied both full time and part time. The results collected by means of 100 correctly filled study questionnaires were processed using statistical analysis tools. The survey comprised 16 questions. To answer a question, a respondent had to tick a proper box under a question. The open-ended questions required a written answer to the posed question. In each question, a respondent could choose one or several possible answers. The survey was fully anonymous, and its aim was solely to determine preferences of beverage consumers. At the end of the study, sensory recognition of the selected cola-type drink brand was tested. In the test, five cola-type drink brands known on the market were used, namely, Coca-Cola, Pepsi, Hoop-Cola and two own brands of store chains.

A respondent was presented with five non-marked samples and the reference sample. He or she was then tasked with identifying which of the five samples is identical with the reference sample in his/her opinion. First, the respondent would taste the reference sample and then each of the five non-marked samples. Before tasting each subsequent sample, the respondent's taste buds were rinsed with distilled water. In the course of the study a considerable amount of research material was obtained that allowed cross analyses to be conducted.

\section{Results}

Due to vast amount of the obtained research material, only a selected part of it was presented. Figure 1 shows the characteristics of the study group.

The study involved 100 individuals, slightly over half of whom were women. The group was diverse in terms of place of residence, most of the respondents were final year students at universities or colleges and were in good mood. Subsequent questions concerned the matter of smoking cigarettes and the frequency of alcohol consumption (Fig. 2). Most of the study participants were non-smokers and in terms of the frequency of alcohol consumption the group of students was diverse. 


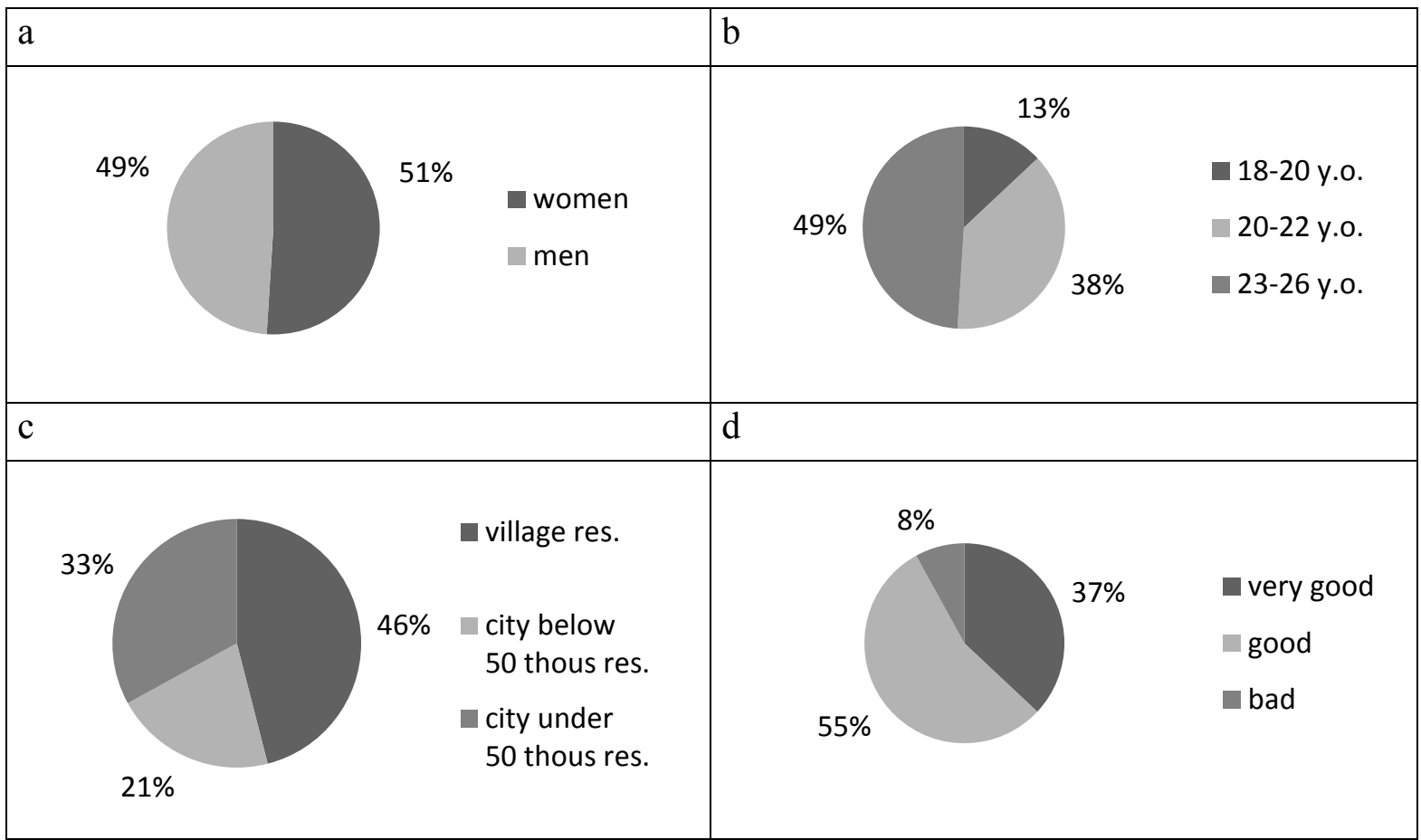

Figure 1. Characteristics of the study group: a) sex, b) age, c) place of residence, d) frame of mind. Adapted from: own study.

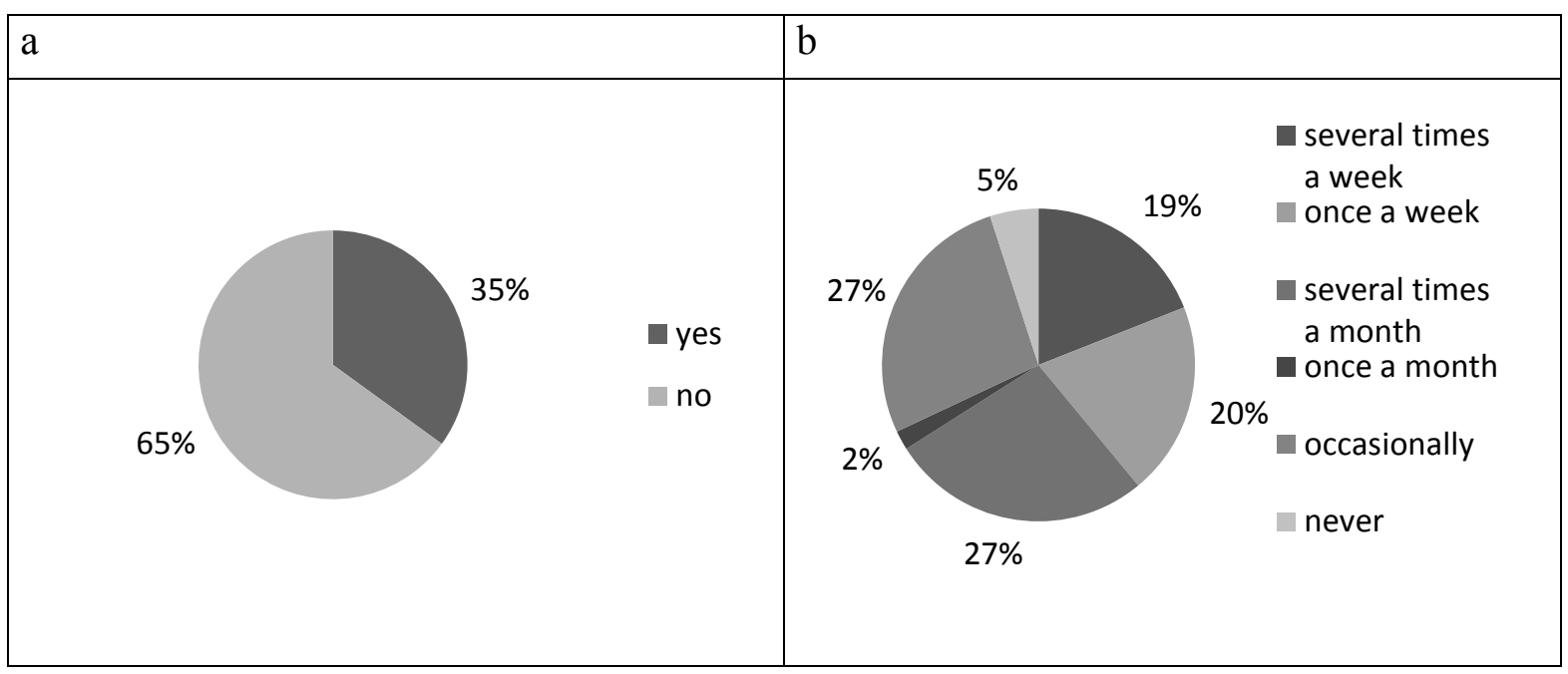

Figure 2. Characteristics of the study group: a) smokers, b) frequency of alcohol consumption. Adapted from: own study.

In Fig. 3, the respondents' answers to questions concerning the frequency of consumption of cola-like beverages are shown as well as the matter of brands they choose. Only $2 \%$ of the students responded that they never drink this kind of beverages, while the brand they prefer by far is Coca-Cola (48\%). It should be added that over $75 \%$ of the respondents reported to choose Coca-Cola and Pepsi. 


\begin{tabular}{|c|c|c|c|}
\hline $\mathrm{a}$ & & $b$ & \\
\hline $2 \% 5 \%$ & $\begin{array}{l}\text { " daily } \\
\text { w several times } \\
\text { a week } \\
\text { n several times } \\
\text { a month } \\
\text { - several times } \\
\text { a year } \\
\text { never }\end{array}$ & $24 \%$ & $\begin{array}{l}\text { coca-cola } \\
\text { pepsi } \\
\text { wop cola } \\
\text { coca-cola } \\
\text { zero } \\
\text { pepsi max } \\
\text { other brand } \\
\text { I don't buy }\end{array}$ \\
\hline
\end{tabular}

Figure 3. Characteristics of the study group: a) frequency of cola-type soft drinks consumption, b) brand chosen in study group. Adapted from: own study.

Figure 4 presents factors that affect the respondents' choice of a given beverage. They put the highest importance on product quality, brand and price, while less attention is given to the type of packaging and the place of purchase.

In Fig. 5, results of the study on the sensory recognition of selected brands of cola-type beverages are presented. The sample marked 4 was the reference sample. It was Coca-Cola. Its sensory qualities were identified by half of the study participants. As many as $20 \%$ of the respondents identified sample marked 3 as the reference sample. It was Pepsi.

At the end of the study, cross analyses were performed. Figure 6 presents results of the study concerning the sensory recognition among smokers and smokers who consumed alcohol several times a week. The obtained recognition indicators were lower than in the remaining part of the group. 


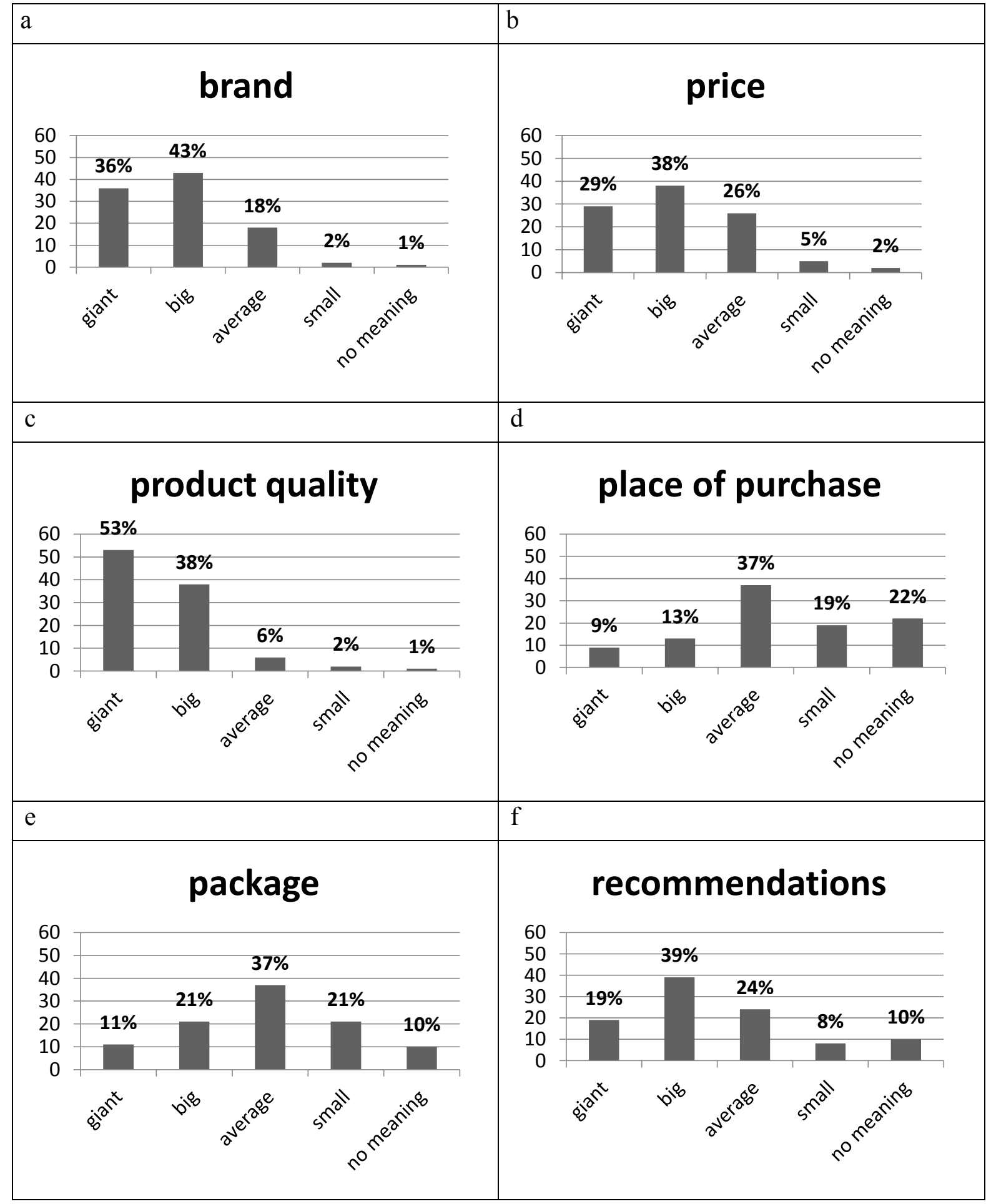

Figure 4. Factors influencing on consumer's decisions. Adapted from: own study. 


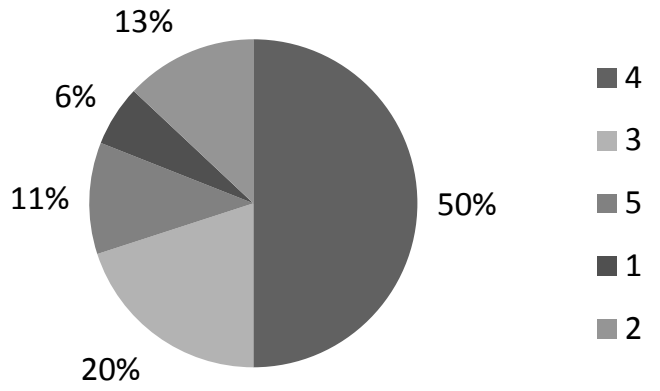

Figure 5. Sensory identification of cola-type soft drinks among students. Adapted from: own study.

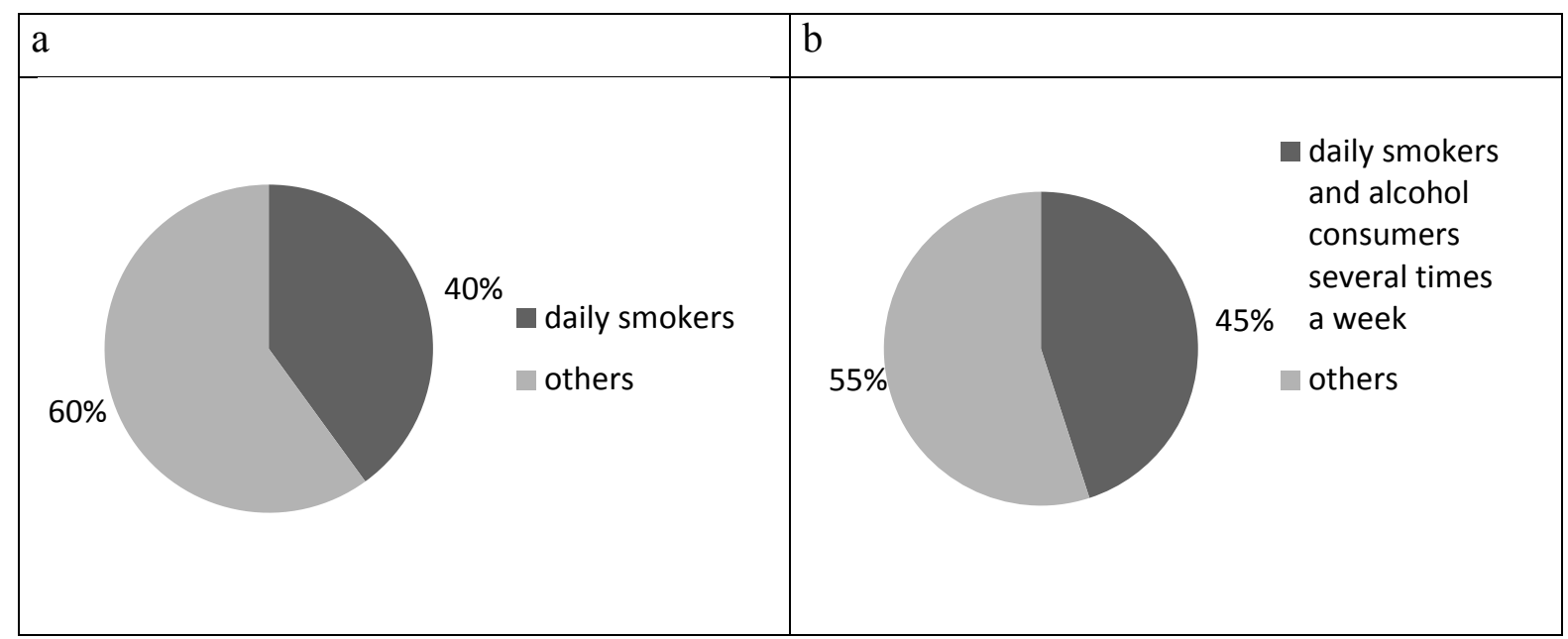

Figure 6. Sensory identification of cola-type soft drinks among: a) smokers, b) alcohol consumers. Adapted from: own study.

\section{Summary}

Based on the conducted studies, it can be concluded that:

1. The group of respondents was diverse in terms of sex, on the day of measurement it was characterised by good mood, in most cases inhabited rural areas and comprised students aged 23-26 years.

2. $65 \%$ of the respondents were non-smokers and the group was diversified in terms of the frequency of alcohol consumption.

3. The brand of beverage that was most popular among the respondents was Coca-Cola and in most cases drinks of this sort are consumed by them several times a month.

4. The greatest effect on the respondents at the time of deciding on the purchase was exerted by product quality, brand and price.

5. The reference sample was recognised by $50 \%$ of the respondents.

6. Smokers and smokers who consumed alcohol often showed sensory sensitivity lower by $10 \%$ and $5 \%$ respectively compared to the group average. 
7. Cola-type soft drinks was consumed at least once a week.

8. As many as $49 \%$ of the students admitted to purchasing 3 or 4 cola-type soft drinks at a time.

9. The respondents who prefer to shop in grocery stores constitute $43 \%$ of the study participants.

10. The most popular type of cola-type soft drink is Coca cola chosen by $48 \%$ of the respondents.

11. The most important factor affecting the choice during the purchase of a cola-type soft drinks is brand, considered the most significant factor by $42 \%$ of the students.

12. A vast majority of the study participants (as many as 59\%) chose the 0.5 litre bottle as the most common packaging.

13. The respondents pay no attention to the type of the selected packaging. The answer "It is not important for me" was chosen by $56 \%$ of the students.

14. As many as $43 \%$ of the study participants also attribute no significance to the type of packaging and the type of closure of a given packaging.

15. The sensory recognition of a brand may be considered high as it amounted to $50 \%$.

\section{References}

1. Altkorn, J. (1999). Strategia marki. Warszawa: PWE.

2. Babicz-Zielińska, E., and Jeżewska-Zychowicz, M., and Laskowski, W. (2010). Żywność. Nauka. Technologia. Jakość, 4(71), 141-153.

3. Baryłko-Pikielna, N., and Matuszewska I. (2009). Sensoryczne badania żywności. Wydawnictwo Naukowe PTTŻ.

4. Budsławski, J., and Drabant, Z. (1972). Metody analizy żywności. Warszawa: WNT.

5. Chrąchol, U. (2009). Marketing szeptany jako efektywny sposób kreowania marki wśród konsumentów. Zeszyty Naukowe Uniwersytetu Szczecińskiego, Ekonomiczne Problemy Usług, 42. Marketing przyszłości. Trendy, Strategie. Instrumenty. Współczesne wyzwania komunikacji marketingowej. Szczecin, 417-421.

6. Dębski, M. (2009). Kreowanie silnej marki, Warszawa: PWE.

7. Gawęcki, J., and Baryłko-Pikielna, N. (2015). Zmyst a jakość żywności i żywienia. Poznań: Wyd. Uniwersytetu Przyrodniczego.

8. Gawęcki, J., and Jędryka, T. (2001). Analiza sensoryczna. Wybrane metody i przykłady zastosowań. Poznań: Wyd. Akademii Ekonomicznej.

9. Gondek, E., and Marzec, A. (2007). Sensoryczna ocena tekstury pieczywa chrupkiego o zróżnicowanej aktywności wody. Inżyniera Rolnicza, 5(93), 169-177. 
10. Małecka, M. (2003). Wybrane metody analizy żywności. Poznań: Wydawnictwo Akademii Ekonomicznej.

11. Popiel, D. (2005). Ochrona prawna marki Instrumenty kształtowania wizerunku marki. A. Grzegorczyk (ed.). Warszawa: Wyższa Szkoła Promocji, 1-21.

12. Szymańska, A. (2005). Pozycja firmy Coca-Cola na polskim rynku napojów gazowanych. Zeszyty Naukowe AE w Krakowie, 659, 1-15.

13. Urban, S. (1998). Marketing produktów spożywczych. Wrocław: Wyd. Akademii Ekonomicznej im. Oskara Langego. 